Pathophysiology of Haemostasis and Thrombosis

\title{
Serine Proteases Affecting Blood Coagulation and Fibrinolysis from Snake Venoms
}

\author{
R. Manjunatha Kini \\ Department of Biological Sciences, Faculty of Science, National University of Singapore, Singapore; \\ Department of Biochemistry, VCU Medical Center, Virginia Commonwealth University, Richmond, Va., USA
}

\author{
Key Words \\ Procoagulant - Anticoagulant $\cdot$ Thrombin-like enzyme • \\ Protein $\mathrm{C}$ activator $\cdot$ Factor $\mathrm{V}$ activator $\cdot$ Prothrombin \\ activator Plasminogen activator
}

\begin{abstract}
Snake venom proteases, in addition to their contribution to the digestion of the prey, affect various physiological functions. They affect platelet aggregation, blood coagulation, fibrinolysis, complement system, blood pressure and nervous system. This review provides a ready reference for serine proteases that interfere in blood coagulation and fibrinolysis. They exhibit their activity by activation of specific zymogens of coagulation factors. These serine proteases serve as tools to study molecular details in the activation of specific factors involved in coagulation and fibrinolytic cascades and are useful in treating various thrombotic and hemostatic conditions.
\end{abstract}

Copyright (C) 2005 S. Karger AG, Basel

\section{Introduction}

Snake venoms are cocktails of pharmacologically active proteins and peptides. They are used as offensive weapons in immobilizing, killing and digesting the preys
$[1,2]$. Some of these toxins exhibit various enzymatic activities, whereas others are nonenzymatic proteins. Most enzymes found in snake venoms are hydrolases that breakdown biological molecules including proteins, nucleic acids and phospholipids. In addition to their contribution to the digestion of the prey, a number of these hydrolases exhibit specific pharmacological effects. Snake venoms, particularly crotalid and viperid venoms, are rich sources of serine proteases and metalloproteases. These proteases affect various physiological functions. They affect platelet aggregation, blood coagulation, fibrinolysis, complement system, blood pressure and nervous system. This short review describes a number of serine proteases that interfere in blood coagulation and fibrinolysis.

\section{Procoagulant Proteases}

All the procoagulants from snake venoms characterized to date are proteases; they activate a zymogen of specific coagulation factor in the coagulation cascade and hasten clot formation. Some venom proteases also activate the protein cofactor, factor V. For example, RVV-V (Daboia russelli) and thrombocytin (Bothrops atrox) activate factor $\mathrm{V}$, the cofactor in the prothrombinase complex (reviewed in $[3,4]$ ).

\section{KARGER}

Fax +4161306 1234 E-Mail karger@karger.ch www.karger.com
R. Manjunatha Kini

Protein Science Laboratory, Department of Biological Sciences Faculty of Science, 14 Science Drive 4

National University of Singapore, Singapore 117543 (Singapore)

Tel. +65 6874 5235, Fax +656779 2486, E-Mail dbskinim@nus.edu.sg 
Factor VII Activators

So far, snake venom proteins that specifically activate only factor VII are not known. However, oscutarin, a group C prothrombin activator (see below) from Oxyuranus scutellatus venom activates factor VII [5]. Gel electrophoresis analysis of the cleavage products indicated that activation occurred at a site similar to the natural cleavage site. The activation of factor VII, similar to that of prothrombin, was greatly potentiated by $\mathrm{Ca}^{2+}$ ions and phospholipids, and was not dependent upon the presence of its factor Va-like subunit [6]. The structural details of oscutarin and related proteins are given below.

\section{Factor X Activators}

Venoms from Viperidae, Crotalidae and Elapidae contain a variety of proteases capable of activating factor $\mathrm{X}$ (for reviews, see [6, 7]). They are either metalloproteases or serine proteases. The factor $\mathrm{X}$ activator from Russell's viper (Daboia russelli) venom (RVV-X) is a metalloprotease that has been well characterized (for details, see [6]). So far, a few serine proteases that activate factor $\mathrm{X}$ have also been isolated from the venoms of Ophiophagus hannah, Bungarus fasciatus, Cerastes cerastes and Cerastes vipera (for references, see the review [6]). These serine proteases vary in their size. However, currently no structural details are available on any of these proteins.

\section{Prothrombin Activators}

A large number of snake species contain prothrombin activators in their venoms (for an inventory, see [8] and for reviews, see [9-14]). Based on their structural properties, functional characteristics and cofactor requirements, they have been categorized into four groups [8, 15-16]. Groups A and B prothrombin activators are metalloproteases and they convert thrombin to meizothrombin. In contrast, groups $\mathrm{C}$ and $\mathrm{D}$ prothrombin activators are serine proteases and they convert prothrombin to mature thrombin. Here, I will discuss some of the salient features of only these two latter groups. They have been found so far only in the venoms of Australian elapids. For more details, readers are advised to read recent reviews on prothrombin activators [12-14].

\section{Group C Prothrombin Activators}

This group of serine proteases requires only $\mathrm{Ca}^{2+}$ ions and negatively charged phospholipids, but not factor Va, for maximal activity [15]. They have been purified and characterized from Oxyuranus scutellatus [17-19] and Pseudonaja textilis venoms [20-23]. The native activators have a molecular mass of $\sim 300 \mathrm{kDa}$ and consist of a factor Xa-like catalytic subunit $(60 \mathrm{kDa})$ and a factor Valike cofactor subunit $(\sim 200 \mathrm{kDa})$. The two chains of the factor Xa-like catalytic subunit are disulfide-linked, whereas the two chains of the factor Va-like cofactor are held together by non covalent interactions. The catalytic subunit, similar to factor $\mathrm{Xa}$, has weak catalytic activity in isolation, which is greatly stimulated by the presence of the factor Va-like subunit $[19,21]$. These activators cleave at both $\operatorname{Arg}_{271}-\mathrm{Thr}_{272}$ and $\mathrm{Arg}_{320}-\mathrm{Ile}_{321}$ bonds of prothrombin [19], converting it to mature thrombin, in contrast to groups A and B activators, which only convert prothrombin to meizothrombin. We have shown that the group $\mathrm{C}$ prothrombin activators structurally and functionally resemble the mammalian factor $\mathrm{Xa}-\mathrm{Va}$ complex [21-23].

\section{Group D Prothrombin Activators}

The activities of these serine proteases are strongly stimulated by $\mathrm{Ca}^{2+}$ ions, factor $\mathrm{Va}$ and negatively charged phospholipid vesicles [24-27]. They are serine proteases with molecular mass ranging from 45 to $47 \mathrm{kDa}[28,29]$. They have two chains held together by disulfide bonds. The serine protease active site is located in the heavy chain $[27,28]$.

They exhibit potent procoagulant effects, comparable to mammalian factor Xa, through activation of prothrombin $[27,28]$. Similar to factor Xa, they cleave prothrombin at two sites, $\operatorname{Arg}_{271}-\mathrm{Thr}_{272}$ and $\operatorname{Arg}_{320}-\mathrm{Ile}_{321}$. Their poor activator activity is stimulated by more than a million-fold by negatively charged phospholipids, factor Va and $\mathrm{Ca}^{2+}$ ions. They also hydrolyze factor Xa-specific chromogenic substrates [27,28]. Recently, we determined the complete amino acid sequences of trocarin D [28] and hopsarin D [29]. They share high identity (53-60\%) and similarity (62-70\%), and hence similar domain architecture, with factor $\mathrm{Xa}[28,29]$. Their light chains consist of an N-terminal Gla domain (residues 1-39), followed by two epidermal growth factor-like domains, EGF-I (residues 50-81) and EGF-II (residues 89-124). Thus, group $\mathrm{D}$ venom prothrombin activators are true structural and functional homologues of blood coagulation factors [28, 29].

\section{Thrombin-Like Enzymes}

The thrombin-like enzymes (TLEs) are widely distributed within several pit viper genera (Agkistrodon, Bothrops, Crotalus, Lachesis and Trimeresurus), as well as some true vipers (Bitis and Cerastes) and the colubrid, Dispholidus typus (for an inventory and reviews, see [3032]). They are single-chain serine proteases (for example, 
see [33]), except for the enzyme from Cerastes cerastes, which is reported to consist of two identical disulfidelinked chains [34]. These serine proteases have a molecular mass of 26-33 kDa. Some of them are glycoproteins. They share a high degree of sequence identity among themselves $(\sim 67 \%)$. However, they show less than $40 \%$ similarity with human thrombin. The presence of Asp 189 in all the TLEs explains their cleavage of arginyl bonds in fibrinogen, as this is the specificity pocket residue common to all serine proteases that hydrolyze peptide bonds after basic residues [32]. They preferentially release either fibrinopeptide A or B, rarely both with equal efficiency, unlike thrombin $[31,35]$. Secondary cleavages are also often seen. They also show a fair degree of species specificity in the efficiency of fibrinogen conversion. Classical low-molecular-weight serine protease inhibitors inhibit TLEs, but most are not inhibited by thrombin inhibitors like antithrombin III and hirudin $[31,35,36]$. They act on blood plasma and induce friable and translucent clots presumably due to lack of crosslinking of fibrin by factor XIIIa. TLEs often also act on coagulation factor XIII, but appear to degrade rather than activate it [36]. Unlike thrombin, TLEs do not activate other coagulation factors [35]. Thus, although TLEs 'resemble' thrombin to an extent, they are structurally and functionally dissimilar to the coagulation factor $[12,31$, 36]. These unique properties enable their clinical use as defibrinogenating agents; for example, ancrod (Arvin ${ }^{\circledR}$; Calloselasma rhodostoma) and batroxobin (Defibrase ${ }^{\circledR}$; Bothrops atrox moojeni [37]) (reviewed in [37, 38]). Since the fibrin formed is not cross-linked, it is readily degraded by the fibrinolytic system. TLEs are clinically well tolerated with no or only minimal side effects [31].

\section{Anticoagulant Proteases}

Anticoagulants from snake venoms prolong clot formation; they are enzymes, such as serine and metalloproteases, or nonenzymatic proteins, such as C-type lectinrelated proteins and three-finger toxins. The anticoagulant effects of phospholipase $A_{2}$ enzymes, metalloproteases and nonenzymatic proteins are beyond the scope of this review and interested readers should consult recent reviews on these topics [39-43].

\section{Protein C Activators}

Protein $\mathrm{C}$ is an anticoagulant protein circulating in the blood as zymogen. Upon activation by thrombin, activated protein $\mathrm{C}$ degrades factors V/Va and VIII/VIIIa and releases a tissue-type plasminogen activator. It also stimulates fibrinolysis through its interaction with plasminogen activator inhibitor [44-46]. A number of snake venoms specifically activate protein C [47]. Venoms from snake species belonging Agkistrodon genus (A. contortrix contortrix, A. c. mokasen, A. c. pictigaster, A. piscivorus, A. p. leucostoma, A. halys halys, A. blomhoffi ussuriensis and $A$. bilineatus) contain protein $\mathrm{C}$ activators. They have been purified from A. c. contortrix [47-52], A. bilineatus [53], A. h. halys [54], and A. blomhoffi ussuriensis [55]. They are glycoproteins with a molecular mass of $\sim 36-40 \mathrm{kDa}$. These serine proteases activate protein $\mathrm{C}$ at low salt concentration in the absence of $\mathrm{Ca}^{2+}$ ions. High salt and $\mathrm{Ca}^{2+}$ ions inhibit their ability to activate protein C $[49,51,54]$. So far, amino acid sequence of only the protein $C$ activator from $A$. c. contortrix venom has been determined [56]. Protein $\mathrm{C}$ activators are used as diagnostic agents in the estimation of protein $C[57,58]$. They prolong clotting times $[47,48]$ and thrombus formation in the arterio-venous shunt [55] in vivo.

\section{Fibrinolytic Proteases}

Physiologically, plasmin plays a pivotal role in fibrinolysis. Some venom proteases contribute to fibrinolysis directly by the activation of plasminogen to plasmin (see below). Metalloproteases that digest and degrade fibrinogen and fibrin are beyond the scope of this review.

\section{Plasminogen Activators}

Plasminogen activators have been purified from the venoms of Trimeresurus stejnegeri (TSV-PA) [59], Agkistrodon halys (Halys-PA) [60] and Lachesis muta muta (LV-PA) [61]. These serine proteases are acidic glycoproteins with a molecular mass of $33 \mathrm{kDa}$. TSV-PA activates plasminogen by a single cleavage at the peptide bond $\operatorname{Arg}_{561}-\mathrm{Val}_{562}$ [59]. Based on the molecular model and crystal structure [62], Bon and coworkers [63-65] have studied the structure-function relationships of TSV-PA. They have shown that Phe193 plays an important role in binding to the substrate plasminogen and the inhibitors $[64,65]$. Replacement of Phe193 by Gly results in 8-9fold increased activity on plasminogen [64]. The mutant is 100-fold more susceptible to plasminogen activator inhibitor 1 (PAI-1) and $\alpha_{2}$-antiplasmin [65]. In addition, 37-loop of TSV-PA plays a crucial role in its resistance to inhibition by protease inhibitors [65] (for details, see the review [66]). 


\section{Summary and Future Prospects}

Snake venom serine proteases and their complexes have evolved by gene duplication and accelerated evolution $[67,68]$ to activate 'critical' proteins and interfere in the coagulation cascade. They contribute to venom toxicity. However, a number of these proteases are being used in diagnostics as well as clinical treatment. Further, their studies contribute to our understanding of structurefunction relationships of blood coagulation factors.

\section{References}

1 Harvey AL: Snake Toxins. New York, Perga- 17 Owen WG, Jackson CM: Activation of promon, 1991.

2 Tu AT: Reptile Venoms and Toxins. New York, Marcel Decker, 1991.

3 Tokunaga F, Iwanaga S: Proteases activating factor V; in Bailey GS (ed): Enzymes from Snake Venom, Fort Collins, CO, Alaken Inc., 1998, pp 209-225.

-4 Rosing J, Govers-Riemslag JWP, Yukelson L, Tans G: Factor V activation and inactivation by venom proteases. Haemostasis 2001;31: 241-246.

$\checkmark 5$ Nakagaki T, Lin P, Kisiel W: Activation of human factor VII by the prothrombin activator from the venom of Oxyuranus scutellatus (Taipan snake). Thromb Res 1992;65:105-116.

6 Morita T: Proteases which activate factor X; in Bailey GS (ed): Enzymes from Snake Venom, Fort Collins, CO, Alaken Inc., 1998, pp 179208.

7 Tans G, Rosing J: Snake venom activators of factor X: an overview. Haemostasis 2001;31: 225-233.

$>8$ Rosing J, Tans G: Inventory of exogenous prothrombin activators. Thromb Haemost 1991; 65:627-630.

$\checkmark 9$ Rosing J, Tans G: Structural and functional properties of snake venom prothrombin activators. Toxicon 1992;30:1515-1527.

10 Tans G, Rosing J: Prothrombin activation by snake venom proteases. J Toxicol 1993;12: 155-173.

11 Petrovan R, Tans G, Rosing J: Proteases activating prothrombin; in Bailey GS (ed): Enzymes from Snake Venom, Fort Collins, CO, Alaken Inc., 1998, pp 227-252.

12 Kini RM, Joseph JS, Rao VS: Prothrombin activators from snake venoms; in Mènez A (ed): Perspectives in Molecular Toxinology. Chichester, England, John Wiley, pp 341-355.

$\checkmark 13$ Joseph JS, Kini RM: Snake venom prothrombin activators similar to blood coagulation factor Xa. Curr Drug Targets Cardiovasc Haematol Disord 2004;4:397-416.

14 Kini RM: The intriguing world of prothrombin activators from snake venoms. Toxicon 2005; 45:1133-1145.

15 Kini RM, Morita T, Rosing J: Classification and nomenclature of prothrombin activators isolated from snake venoms. Thromb Haemost 2001;85:710-711.

16 Yamada D, Sekiya F, Morita T: Isolation and characterization of carinactivase, a novel prothrombin activator in Echis carinatus venom with a unique catalytic mechanism. J Biol Chem 1996;271:5200-5207. thrombin with Oxyuranus scutellatus scutellatus (Taipan snake) venom. Thromb Res 1973; 3:705-714.

18 Walker FJ, Owen WG, Esmon CT: Characterization of the prothrombin activator from the venom of Oxyuranus scutellatus scutellatus (Taipan venom). Biochemistry 1980;19:10201023.

19 Speijer H, Govers-Riemslag JWP, Zwaal RFA, Rosing J: Prothrombin activation by an activator from the venom of Oxyuranus scutellatus (Taipan snake). J Biol Chem 1986;261:1325813267.

20 Masci PP, Whitaker AN, de Jersey J: Purification and characterization of the prothrombin activator of the venom of Pseudonaja textilis; in Gopalakrishnakone P, Tan CK (eds): Progress in Venom and Toxin Research, Proc First Asia-Pacific Congr Animal, Plant Microb Toxins, Singapore, National University of Singapore, 1987, pp 209-219.

21 Rao VS, Kini RM: Pseutarin C, a prothrombin activator from Pseudonaja textilis venom: its structural and functional similarity to mammalian coagulation factor Xa-Va complex. Thromb Haemost 2002;88:611-619.

$\checkmark 22$ Rao VS, Swarup S, Kini RM: The nonenzymatic subunit of pseutarin $\mathrm{C}$, a prothrombin activator from common brown snake (Pseudonaja textilis) venom, shows structural similarity to mammalian coagulation factor $\mathrm{V}$. Blood 2003;102:1347-1354.

23 Rao VS, Swarup S, Kini RM: The catalytic subunit of pseutarin $\mathrm{C}$, a group $\mathrm{C}$ prothrombin activator from the venom of Pseudonaja textilis, is structurally similar to mammalian blood coagulation factor Xa. Thromb Haemost 2004; 92:509-521.

24 Jobin F, Esnouf MP: Coagulant activity of tiger snake (Notechis scutatus scutatus) venom. Nature 1966;211:873-875.

25 Chester A, Crawford GPM: In vitro coagulant properties of venoms from Australian snakes. Toxicon 1982;20:501-504.

26 Marshall LR, Herrmann RP: Coagulant and anticoagulant actions of Australian snake venoms. Thromb Haemost 1983;50:707-711.

27 Tans G, Govers-Riemslag JWP, van Rihn JLML, Rosing J: Purification and properties of a prothrombin activator from the venom of Notechis scutatus scutatus. J Biol Chem 1985; 260:9366-9372.
8 Joseph JS, Chung MC, Jeyaseelan K, Kini RM: Amino acid sequence of trocarin, a prothrombin activator from Tropidechis carinatus venom: its structural similarity to coagulation factor Xa. Blood 1999;94:621-631.

29 Rao VS, Joseph JS, Kini RM: Group D prothrombin activators from snake venom are structural homologues of mammalian blood coagulation factor Xa. Biochem J 2003;369: 635-642.

30 Pirkle H, Stocker K: Thrombin-like enzymes from snake venoms; an inventory. Thromb Haemost 1991;65:444-450.

31 Bell WR Jr: Defibrinogenating enzymes. Drugs 1997;54:18-30.

32 Pirkle H, Theodor I: Thrombin-like enzymes; in Bailey GS (ed): Enzymes from Snake Venom, Fort Collins, CO, Alaken Inc., 1998, pp 39-69.

33 Au LC, Lin SB, Chou JS, Teh GW, Chang KJ, Shih CM: Molecular cloning and sequence analysis of the cDNA for ancrod, a thrombinlike enzyme from the venom of Calloselasma rhodostoma. Biochem J 1993;294:387-390.

34 Laraba-Djebari B, Martin-Eauclaire M-F, Marchot P: A fibrinogen-clotting serine proteinase from Cerastes cerastes (horned viper) venom with arginine-esterase and amidase activities. Purification, characterization and kinetic parameter determination. Toxicon 1992; 30:1399-1410.

35 Aronson DL: Comparison of the actions of thrombin and the thrombin-like venom enzymes ancrod and batroxobin. Thromb Haemost 1976;36:1-13.

36 Hutton RA, Warrell DA: Action of snake venom components on the haemostatic system. Blood Rev 1993; 7:176-189.

37 Stocker K, Barlow GH: The coagulant enzyme from Bothrops atrox venom (batroxobin). Methods Enzymol 1976;45:214-223.

38 Stocker K: Research, diagnostic and medicinal uses of snake venom enzymes; in Bailey GS (ed): Enzymes from Snake Venom, Fort Collins, CO, Alaken Inc., 1998, pp 705-736.

39 Mounier C, Bon C, Kini RM: Anticoagulant venom and mammalian secreted phospholipases $\mathrm{A}_{2}$ : protein- versus phospholipid-dependent mechanism of action. Haemostasis 2001; 31:279-287.

40 Kini RM: Structure-function relationships and mechanism of anticoagulant phospholipase $A_{2}$ enzymes from snake venoms. Toxicon 2005;45:1147-1161 
41 Swenson S, Toombs CF, Pena L, Johansson J, Markland FS Jr: $\alpha$-fibrinogenases. Curr Drug Targets Cardiovasc Haematol Disord 2004;4: 417-435.

42 Morita T: C-type lectin-related proteins from snake venoms. Curr Drug Targets Cardiovasc Haematol Dis 2004; 4:357-373.

43 Morita T: Structures and functions of snake venom CLPs (C-type lectin-like proteins) with anticoagulant-, procoagulant-, and plateletmodulating activities. Toxicon 2005;45:1099_ 1114.

-44 Fay WP, Owen WG: Platelet plasminogen activator inhibitor: purification and characterization of interaction with plasminogen activators and activated protein C. Biochemistry 1989;28:5773-5778.

45 Moniwa N: Relationship of urokinase type plasminogen activator, plasminogen activator inhibitor type 1 and activated protein $\mathrm{C}$ in fibrinolysis of human placenta. Pol J Pharmacol 1996;48:215-220.

-46 Sakamoto T, Ogawa H, Takazoe K, Yoshimura $\mathrm{M}$, Shimomura $\mathrm{H}$, Moriyama $\mathrm{Y}$, Arai $\mathrm{H}$, Okajima K: Effect of activated protein $\mathrm{C}$ on plasma plasminogen activator inhibitor activity in patients with acute myocardial infarction treated with alteplase: comparison with unfractionated heparin. J Am Coll Cardiol 2003; 42:1389-1394.

-47 Stocker K, Fischer H, Meier J, Brogli M, Svendsen L: Protein C activators in snake venoms. Behring Inst Mitt 1986;79:37-47.

48 Stocker K, Fischer H, Meier J, Brogli M, Svendsen L: Characterization of the protein C activator Protac from the venom of the southern copperhead (Agkistrodon contortrix) snake. Toxicon 1987;25:239-252.

49 Klein JD, Walker FJ: Purification of a protein $\mathrm{C}$ activator from the venom of the southern copperhead snake (Agkistrodon contortrix contortrix). Biochemistry 1986;25:4175-4179.

50 Kisiel W, Choi E, Kondo S: Isolation of a protein $\mathrm{C}$ activator from southern copperhead venom. Biochem Biophys Res Commun 1987; 143:917-922.
1 Kisiel W, Kondo S, Smith KJ, McMullen BA, Smith LF: Characterization of a protein C activator from Agkistrodon contortrix contortrix venom. J Biol Chem 1987;262:12607-12613.

2 Orthner CL, Bhattacharya P, Strickland DK: Characterization of a protein $\mathrm{C}$ activator from the venom of Agkistrodon contortrix contortrix. Biochemistry 1988;27:2558-2564.

53 Nakagaki T, Kazim AL, Kisiel W: Isolation and characterization of a protein $\mathrm{C}$ activator from tropical moccasin venom. Thromb Res 1990;58:593-602.

54 Bakker HM, Tans G, Yukelson LY, JanssenClaessen TW, Bertina RM, Hemker HC, Rosing $\mathrm{J}$ : Protein $\mathrm{C}$ activation by an activator purified from the venom of Agkistrodon halys halys. Blood Coagul Fibrinolysis 1993;4:605614.

55 Kogan AE, Bashkov GV, Bobruskin ID, Romanova EP, Makarov VA, Strukova SM: Protein Cactivator from the venom of Agkistrodon blomhoffi ussuriensis retards thrombus formation in the arterio-venous shunt in rats. Thromb Res 1993; 70:385-393.

56 McMullen BA, Fujikawa K, Kisiel W: Primary structure of a protein $\mathrm{C}$ activator from Agkistrodon contortrix contortrix venom. Biochemistry 1989;28:674-679.

57 Stocker K, Fischer H, Meier J: Practical application of the protein $\mathrm{C}$ activator Protac from Agkistrodon contortrix venom. Folia Haematol Int Mag Klin Morphol Blutforsch 1988;115: 260-264.

58 Gempeler-Messina PM, Volz K, Buhler B, Muller C: Protein C activators from snake venoms and their diagnostic use. Haemostasis 2001;31:266-272.

59 Zhang Y, Wisner A, Xiong Y, Bon C: A novel plasminogen activator from snake venom. $\mathrm{Pu}$ rification, characterization, and molecular cloning. J Biol Chem 1995;270:1024610255 .
60 Park D, Kim H, Chung K, Kim DS, Yun Y: Expression and characterization of a novel plasminogen activator from Agkistrodon halys venom. Toxicon 1998;36:1807-1819.

61 Sanchez EF, Santos CI, Magalhaes A, Diniz CR, Figueiredo S, Gilroy J, Richardson M: Isolation of a proteinase with plasminogen-activating activity from Lachesis muta muta (bushmaster) snake venom. Arch Biochem Biophys 2000;378:131-141.

62 Parry MA, Jacob U, Huber R, Wisner A, Bon C, Bode W: The crystal structure of the novel snake venom plasminogen activator TSV-PA: a prototype structure for snake venom serine proteinases. Structure 1998;6:1195-1206.

-63 Zhang Y, Wisner A, Maroun RC, Choumet V, Xiong Y, Bon C: Trimeresurus stejnegeri snake venom plasminogen activator. Site-directed mutagenesis and molecular modeling. J Biol Chem 1997;272:20531-20537.

64 Braud S, Parry MA, Maroun R, Bon C, Wisner A: The contribution of residues 192 and 193 to the specificity of snake venom serine proteinases. J Biol Chem 2000;275:1823-1828.

65 Braud S, Le Bonniec BF, Bon C, Wisner A: The stratagem utilized by the plasminogen activator from the snake Trimeresurus stejnegeri to escape serpins. Biochemistry 2002;41:84788484.

66 Wisner A, Braud S, Bon C: Snake venom proteinases as tools in hemostasis studies: structure-function relationship of a plasminogen activator purified from Trimeresurus stejnegeri venom. Haemostasis 2001;31:133-140.

67 Deshimaru M, Ogawa T, Nakashima K, Nobuhisa I, Chijiwa T, Shimohigashi Y, Fukumaki Y, Niwa M, Yamashina I, Hattori S, Ohno M: Accelerated evolution of crotalinae snake venom gland serine proteases. FEBS Lett 1996;397:83-88

68 Saguchi K, Hagiwara-Saguchi Y, Murayama N, Ohi H, Fujita Y, Camargo AC, Serrano SM, Higuchi S: Molecular cloning of serine proteinases from Bothrops jararaca venom gland. Toxicon 2005;46:72-83. 